\title{
Anesthetic Management of a Child with $\beta$-Thalassemia Major and Cortical Venous Thrombosis
}

\author{
Mayank Tyagi ${ }^{1}$ Surya K. Dube ${ }^{1, \odot}$ Vanitha Rajagopalan ${ }^{1, \odot} \quad$ Gyaninder P. Singh ${ }^{1, \odot}$ \\ ${ }^{1}$ Department of Neuroanaesthesiology and Critical Care, All India \\ Institute of Medical Sciences, New Delhi, India

\begin{abstract}
Address for correspondence Surya K. Dube, MD, DM, Department of Neuroanaesthesiology and Critical Care, 7th Floor, Neurosciences Center, All India Institute of Medical Sciences, New Delhi 110029,
\end{abstract} \\ India (e-mail: surya.dube@yahoo.co.in).
}

J Neuroanaesthesiol Crit Care 2021;8:217-220.

\begin{abstract}
$\beta$-thalassemia are a group of inherited blood disorders with reduced hemoglobin levels. $\beta$-thalassemia major is the severe form of disease, and the patients often display

Keywords

- beta-thalassemia major

- cortical venous thrombosis

- decompressive hemicraniectomy an array of associated organ dysfunction which thus increase the risk associated with surgery and anesthesia. Patients with $\beta$-thalassemia major can have multiple pathological defects that may lead to thromboembolic events. Here, we report such a case who was complicated by occurrence of cerebral sinus thrombosis and presented for decompressive hemicraniectomy under general anesthesia. The anesthetic challenges during in such scenario have been discussed.
\end{abstract}

\section{Introduction}

Patients with $\beta$-thalassemia major have a chronic hypercoagulable state with increased incidence of thromboembolic episodes. There are multiple pathological defects that lead to thromboembolic events, which may be life threatening. Cortical venous thrombosis with raised intracranial pressure presenting for emergency decompressive hemicraniectomy is one such condition. We report here a case of $\beta$-thalassemia major complicated by cerebral sinus thrombosis, who presented for decompressive hemicraniectomy under general anesthesia. We have discussed the anesthetic concerns in management of this patient. In addition to highlighting the anesthetic challenges this report also emphasizes the importance of increased vigilance in the clinical management of this vulnerable group of patients.

\section{Case Report}

A 13-year-old (weight: $45 \mathrm{~kg}$ and height: $150 \mathrm{~cm}$ ) female child presented to us with multiple episodes of seizures with altered consciousness (Glasgow Coma Scale [GCS] $\mathrm{E}_{1} \mathrm{~V}_{2} \mathrm{M}_{3}$ ).
The seizure lasted more than 3 minutes without regaining consciousness in between and was managed initially by intravenous midazolam $3 \mathrm{mg}$ followed by levetiracetam $10 \mathrm{mg} / \mathrm{kg}$ given over a period of 30 minutes. Her heart rate, noninvasive blood pressure, respiratory rate, and room air oxygen saturation were $121 / \mathrm{min}, 136 / 78 \mathrm{~mm} \mathrm{Hg}, 22 / \mathrm{min}$, and $88 \%$ respectively. She was pale, mildly icteric, and had hepatosplenomegaly. Ultrasonography revealed portal vein hypertension, cholelithiasis, and solitary right kidney. Her partial pressure of oxygen was $64 \mathrm{~mm} \mathrm{Hg}$, and the remarkable blood parameters were serum sodium of $125 \mathrm{mEq} / \mathrm{L}$, hemoglobin of $7.9 \mathrm{~g} / \mathrm{dL}$, platelet count of $80,000 / \mathrm{cm}^{3}$, and prothrombin time (international normalized ratio [INR]) of 1.28. Her electrocardiogram showed prolonged QT interval, and two-dimensional echocardiography revealed an ejection fraction of $55 \%$, grade 2 diastolic dysfunction, and right ventricular enlargement. Her facial features included frontal bossing, malar prominence, and depressed nasal bridge. Airway assessment showed buck teeth and a normal range of neck movement. The patient was a case of $\beta$-thalassemia major (BTM) and was receiving two units of washed red blood cell units every third week along with deferoxamine mesylate. Computed published online

November 19, 2020
DOI https://doi.org/

$10.1055 / \mathrm{s}-0040-1715357$

ISSN 2348-0548.

\footnotetext{
(C) 2020. Indian Society of Neuroanaesthesiology and Critical Care. This is an open access article published by Thieme under the terms of the Creative Commons Attribution-NonDerivative-NonCommercial-License, permitting copying and reproduction so long as the original work is given appropriate credit. Contents may not be used for commercial purposes, or adapted, remixed, transformed or built upon. (https://creativecommons.org/licenses/by-nc-nd/4.0/) Thieme Medical and Scientific Publishers Pvt. Ltd., A-12, 2nd Floor,
} Sector 2, Noida-201301 UP, India 
tomography (CT) head revealed intracerebral hematoma in the left frontoparietal region with perilesional edema and midline shift (-Fig. 1). She was diagnosed to have cortical venous thrombosis (CVT) with midline shift and was scheduled for emergency decompressive hemicraniectomy.

In view of low GCS and seizures, we intubated the patient's trachea with a video laryngoscope (Cormack-Lehane grade $3 \mathrm{~b}$ ), and optimized the patient with packed red cell and platelet transfusion along with electrolyte correction. Initially, mask ventilation seemed difficult due to poor mask fit, but improved after the insertion of an oropharyngeal airway. Anesthesia was induced with titrated doses of propofol and fentanyl and tracheal intubation facilitated with rocuronium. Anesthesia was maintained with total intravenous anesthesia (using propofol and fentanyl) with 50\% oxygen with a target bispectral index of 40 to 60 . We used invasive blood pressure, central venous pressure, noninvasive cardiac output monitoring (FloTrac, Edwards Lifesciences, Irvine, California, United States) and rotational thromboelastometry analysis intraoperatively. Hypertonic saline (3\% $\mathrm{NaCl}$ ) was administered to reduce intracranial pressure. The duration of surgery was 4 hours and 30 minutes, which was uneventful; the total blood loss was $700 \mathrm{~mL}$, and she received two units of packed red cells intraoperatively. Postoperatively, her trachea was extubated after 16 hours and injection phenytoin, deferoxamine mesylate and paracetamol were commenced. For anticoagulation prophylaxis, she received enoxaparin (40 mg) subcutaneously twice daily for 7 days. Warfarin 2.5 mg daily was overlapped during the last 4 days of therapy with the target INR of 2.0 to 3.0. She had a smooth postoperative course (seizures free with no neurological deficit) and was discharged subsequently on a postoperative day 10 with GCS of $E_{4} V_{5} M_{6}$ and intact neurological state.

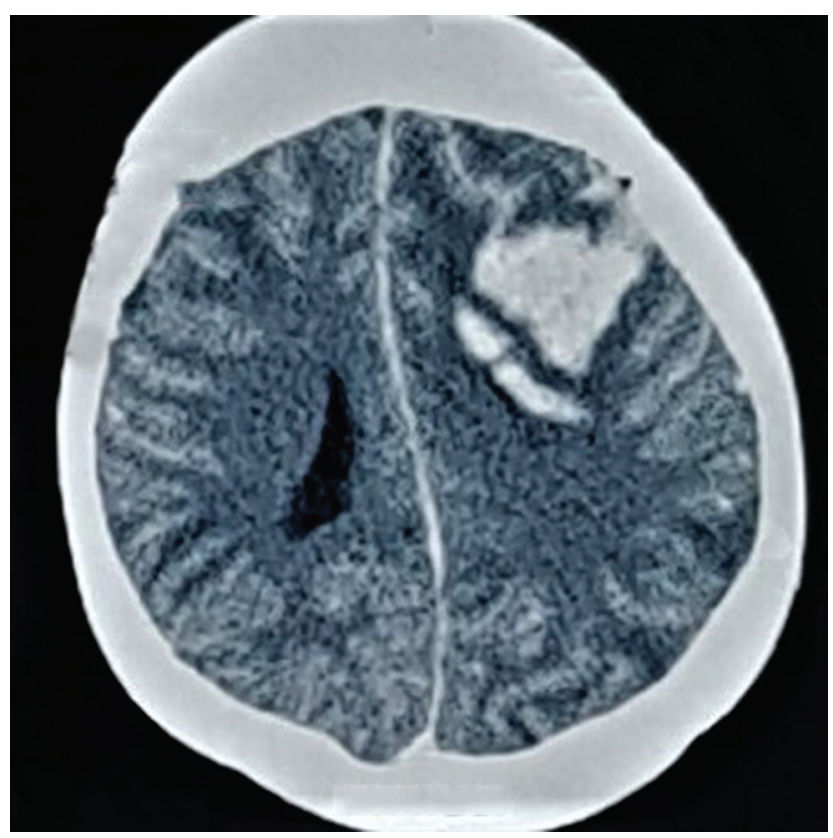

Fig. 1 Intracerebral hematoma in the left frontoparietal region with perilesional edema and midline shift.

\section{Discussion}

Beta-thalassemia disease is one of the most common congenital hemolytic anemia. BTM is a severe form of disease with extramedullary hematopoiesis, hepatosplenomegaly, intravascular hemolysis, and growth retardation. ${ }^{1,2}$ They often display an array of associated organ dysfunction that affects the risk of surgery and anesthesia, and most perioperative deaths occur due to cardiac complications. ${ }^{1,2}$ They are also at increased risk of thromboembolic events that may be life-threatening at times. CVT is a neurological condition linked to hypercoagulable states. Patients with BTM can present with CVT and literature available on the anesthetic management of a thalassemia major patient undergoing decompressive hemicraniectomy for CVT is scarce.

Different anesthetic considerations while managing a patient of BTM with CVT are summarized in - Table 1. CVT accounts for $\sim 0.5$ to $1 \%$ of all strokes, while the reported incidence of pediatric CVT is 0.67 per 100000 children per year. ${ }^{3}$ In patients with BTM with suspected CVT, screening for potential prothrombotic conditions is recommended, and early follow-up with CT venography/magnetic resonance imaging/magnetic resonance venography/transcranial Doppler is required to know about the extent of intracerebral insults. ${ }^{3}$ Supportive measures include appropriate hydration, antibiotics, control of seizure and elevated intracranial pressure, and its complications along with periodic assessments of the visual fields and visual acuity. ${ }^{3}$ The mainstay of treatment in CVT is anticoagulation (adjusted-dose unfractionated heparin or weight-based low molecular wight heparin, and warfarin) followed by vitamin K antagonists. ${ }^{3-5}$ Steroid medications are not recommended. ${ }^{3}$ Agents such as decitabine and hydroxycarbamide and transfusion therapy have been suggested to prevent the complications in CVT. ${ }^{6}$ The side effects of different medications used in the treatment of CVT and BTM are summarized in - Table 2. In patients with neurological deterioration (severe mass effect or intracranial hemorrhage causing intractable intracranial hypertension/herniation) despite medical treatment, decompressive hemicraniectomy is considered. ${ }^{5}$ Endovascular therapy (balloon-assisted thrombectomy or direct catheter thrombolysis) may be considered in patients with failure of initial anticoagulant therapy or in cases having absolute contraindications for anticoagulation therapy. Patients on anticoagulation therapy requiring urgent surgical intervention require a thorough consideration of risk for perioperative intracranial hemorrhage.

\section{Conclusion}

Thalassemia major patient with CVT presents with highly variable clinical spectra and clinically challenging circumstances. Its management needs understanding and optimization of the physiological derangements, intentional search for co-existing systemic abnormalities, anticipating difficult airway and meticulously planned anesthetic techniques. This case reiterates the importance of the multidisciplinary approach and increased vigilance in the clinical management of this vulnerable group of patients. 
Table 1 Systemic manifestations and their anesthetic implications of the $\beta$-thalassemia major and cortical venous thrombosis ${ }^{1-3,5,7-9}$

\begin{tabular}{|c|c|c|c|c|}
\hline Disease & Organ system & Problem & $\begin{array}{l}\text { Pathophysiological } \\
\text { mechanisms }\end{array}$ & Anesthetic considerations \\
\hline \multirow[t]{9}{*}{$\begin{array}{l}\text { Beta- } \\
\text { thalassemia } \\
\text { major }\end{array}$} & Cardiac & $\begin{array}{l}\text { Cardiomegaly, Congestive } \\
\text { cardiac failure, hyperten- } \\
\text { sion, electrophysiological } \\
\text { abnormalities }\end{array}$ & $\begin{array}{l}\text { High output state due } \\
\text { to chronic anemia }\end{array}$ & $\begin{array}{l}\text { Cardiac output monitoring, acid-base } \\
\text { assessment, avoid factors increasing } \\
\text { pulmonary vascular resistance } \\
\text { (hypoxia, hypercarbia, acidosis, } \\
\mathrm{N}_{2} \mathrm{O} \text {, and sympathetic stimulation), } \\
\text { two-dimensional echo to detect } \\
\text { pulmonary hypertension } \\
\text { Maintain stable hemodynamics }\end{array}$ \\
\hline & Respiratory & $\begin{array}{l}\text { Restrictive lung disease, } \\
\text { pulmonary hypertension }\end{array}$ & $\begin{array}{l}\text { Spinal and thoracic } \\
\text { cage deformities }\end{array}$ & $\begin{array}{l}\text { Preoperative pulmonary function test, } \\
\text { chest X-ray, comprehensive systemic } \\
\text { organs examination }\end{array}$ \\
\hline & Muscle & $\begin{array}{l}\text { Decreased weight gain, poor } \\
\text { muscle development (leading } \\
\text { to growth retardation) }\end{array}$ & $\begin{array}{l}\text { Increased metabolic } \\
\text { demand/decreased } \\
\text { supply }\end{array}$ & $\begin{array}{l}\text { Choose drugs with low hepatorenal } \\
\text { metabolism (to avoid longer recovery) }\end{array}$ \\
\hline & Skeletal & $\begin{array}{l}\text { Craniofacial deformities, } \\
\text { pathological fractures, } \\
\text { compression of neural } \\
\text { structures }\end{array}$ & $\begin{array}{l}\text { Ineffective } \\
\text { extramedullary } \\
\text { erythroid tissue expan- } \\
\text { sion, osteopenia and } \\
\text { osteomalacia }\end{array}$ & $\begin{array}{l}\text { Optimal positioning, adequate padding } \\
\text { of pressure points }\end{array}$ \\
\hline & Hematology & $\begin{array}{l}\text { Hypercoagulable } \\
\text { state (increased risk of } \\
\text { thrombosis), intraoperative } \\
\text { systemic hypertension, } \\
\text { Hemolysis/anemia, abnor- } \\
\text { malities in platelet count, } \\
\text { reduced tolerance to bleed- } \\
\text { ing, increased transfusional } \\
\text { risk }\end{array}$ & $\begin{array}{l}\text { Reduced nitric oxide, } \\
\text { multiple blood } \\
\text { transfusion, platelet } \\
\text { and endothelial } \\
\text { activation, decreased } \\
\text { protein C and S level, } \\
\text { disrupted membrane } \\
\text { phospholipids }\end{array}$ & $\begin{array}{l}\text { Thromboelastometry study (for iden- } \\
\text { tifying the cause of coagulopathy and } \\
\text { guiding administration of coagulation } \\
\text { products) and coagulation tests, } \\
\text { avoidance of hypoxemia } \\
\text { Consider blood salvage } \\
\text { Consider risks of neuraxial anesthesia } \\
\text { Prophylactic measures for deep vein } \\
\text { thrombosis/thromboembolic events }\end{array}$ \\
\hline & Immunology & $\begin{array}{l}\text { Immunosuppression, risk of } \\
\text { transmission of blood-borne } \\
\text { infections }\end{array}$ & $\begin{array}{l}\text { Iron overload, chronic } \\
\text { anemia, frequent blood } \\
\text { transfusion }\end{array}$ & $\begin{array}{l}\text { Impaired hemostasis and operative } \\
\text { bleeding } \\
\text { Avoid exposure to blood and body } \\
\text { fluids }\end{array}$ \\
\hline & Hepatic & $\begin{array}{l}\text { Liver failure/fibrosis leading } \\
\text { to cirrhosis, increased risk } \\
\text { of hepatocellular carcinoma } \\
\text { and gall stones, altered drug } \\
\text { metabolism }\end{array}$ & $\begin{array}{l}\text { Chronic hemolysis, } \\
\text { drugs (delayed } \\
\text { clearance, increased } \\
\text { volume of distribution } \\
\text { and prolonged half-life) }\end{array}$ & $\begin{array}{l}\text { Consider drug metabolism and } \\
\text { pharmacokinetics } \\
\text { Avoid drugs undergoing exten- } \\
\text { sive hepatic metabolism (choose } \\
\text { short-acting drugs, e.g., propofol, } \\
\text { fentanyl, and cis-atracurium) }\end{array}$ \\
\hline & Neurology & $\begin{array}{l}\text { Cognitive defects, } \\
\text { neuropsychological } \\
\text { impairment }\end{array}$ & $\begin{array}{l}\text { Chronicity of disease } \\
\text { with emotional and } \\
\text { psychosocial issues }\end{array}$ & $\begin{array}{l}\text { Diminished quality of life, increased } \\
\text { mortality, and poor recovery } \\
\text { postsurgery }\end{array}$ \\
\hline & Airway & $\begin{array}{l}\text { Craniofacial bone deformity } \\
\text { (maxillary hypertrophy, } \\
\text { narrowing of the submental } \\
\text { space, high-arched palate, } \\
\text { prominent zygomatic bones, } \\
\text { nasal bridge depression) }\end{array}$ & $\begin{array}{l}\text { Extramedullary } \\
\text { hematopoiesis }\end{array}$ & $\begin{array}{l}\text { Careful airway assessment (bedside } \\
\text { predictive tests) } \\
\text { Drafting a backup plan, preparation for } \\
\text { difficult airway management, presence } \\
\text { of personnel with expertise }\end{array}$ \\
\hline \multirow[t]{2}{*}{$\begin{array}{l}\text { Cortical venous } \\
\text { thrombosis }\end{array}$} & Cardiorespiratory & $\begin{array}{l}\text { Pulmonary embolism, car- } \\
\text { diac arrest }\end{array}$ & $\begin{array}{l}\text { Thrombi in the micro- } \\
\text { vasculature of lungs }\end{array}$ & $\begin{array}{l}\text { Low lung capacity, hypoxemia, pul- } \\
\text { monary hypertension, and diffusion } \\
\text { defects with associated right heart } \\
\text { failure (Keep fraction of inspired } \\
\text { oxygen } 50 \% \text { or above to avoid any } \\
\text { V/Q mismatch and pulmonary } \\
\text { complications) }\end{array}$ \\
\hline & Neurology & $\begin{array}{l}\text { Headache, scalp vein disten- } \\
\text { sion, and visual disturbances, } \\
\text { intracranial hemorrhage, } \\
\text { focal brain injury, hemipa- } \\
\text { resis and aphasia, increased } \\
\text { intracranial pressure, seizures }\end{array}$ & $\begin{array}{l}\text { Thrombi in the } \\
\text { microvasculature of } \\
\text { brain, impaired venous } \\
\text { drainage, venous } \\
\text { infarction/ischemia or } \\
\text { hemorrhage }\end{array}$ & $\begin{array}{l}\text { Raised intracranial pressure (laryngo- } \\
\text { scopy/ intubation/ adequate depth of } \\
\text { anesthesia), appropriate anesthetic } \\
\text { technique } \\
\text { Brain bulge and Seizure management }\end{array}$ \\
\hline
\end{tabular}


Table 2 Side effect of iron chelating agents and drugs used in the treatment of cortical venous thrombosis 6,10

\begin{tabular}{|l|l|}
\hline Drug & Side effects \\
\hline Decitabine & $\begin{array}{l}\text { Neutropenia, thrombocytopenia, anemia, } \\
\text { fatigue, pyrexia, nausea, cough, petechiae, } \\
\text { constipation, diarrhea, and hyperglycemia }\end{array}$ \\
\hline Hydroxycarbamide & $\begin{array}{l}\text { Increased risk of infection, breathlessness, } \\
\text { bruising, bleeding gums or nosebleeds, } \\
\text { fever, fatigue }\end{array}$ \\
\hline Desferrioxime & $\begin{array}{l}\text { Ocular and retinal toxicity, growth } \\
\text { impairment, ototoxicity, thrombocyto- } \\
\text { penia, abdominal pain, diarrhea, nausea, } \\
\text { vomiting and hypotension, increased risk } \\
\text { of infection }\end{array}$ \\
\hline
\end{tabular}

\section{Conflict of Interest}

None declared.

\section{References}

1 Kallenbach T. Anaesthesia for a patient with beta thalassaemia major. South African J Anaesth Analg [Internet] 2015;21(5):21-24

2 Staikou C, Stavroulakis E, Karmaniolou I. A narrative review of peri-operative management of patients with thalassaemia. Anaesthesia 2014;69(5):494-510
3 Saposnik G, Barinagarrementeria F, Brown RD Jr, et al; American Heart Association Stroke Council and the Council on Epidemiology and Prevention. Diagnosis and management of cerebral venous thrombosis: a statement for healthcare professionals from the American Heart Association/American Stroke Association. Stroke 2011;42(4):1158-1192

4 Yasmin A, O’Keefe YA, Kranz PG, Dombrowski KE, Kolls BJ, James ML. Cerebral venous thrombosis: reviewing pathophysiology, diagnosis, and treatment strategies. J Neuroanaesth Crit Care 2019;06:140-144

5 Keller E, Pangalu A, Fandino J, Könü D, Yonekawa Y. Decompressive craniectomy in severe cerebral venous and dural sinus thrombosis. Acta Neurochir Suppl (Wien) 2005;94(94):177-183

6 Kalantri SA, Ray R, Chattopadhyay A, Bhattacharjee S, Biswas A, Bhattacharyya M. Efficacy of decitabine as hemoglobin $\mathrm{F}$ inducer in $\mathrm{HbE} / \mathrm{\beta}$-thalassemia. Ann Hematol 2018;97(9):1689-1694

7 Succar J, Musallam KM, Taher AT. Thalassemia and venous thromboembolism. Mediterr J Hematol Infect Dis 2011;3(1):e2011025

8 Bharti N, Devrajan J. Difficult airway management in a case of thalassaemia major. Indian J Anaesth 2008;52(1):87-89

9 Eldor A, Rachmilewitz EA. The hypercoagulable state in thalassemia. Blood 2002;99(1):36-43

10 Mobarra N, Shanaki M, Ehteram H, et al. A review on iron chelators in treatment of iron overload syndromes. Int J Hematol Oncol Stem Cell Res 2016;10(4):239-247

\title{
Left Frontal Lobe Tumor-Induced Intraoperative Premature Ventricular Beats
}

\author{
Parmod K. Bithal ${ }^{1, \odot}$ Ravees Jan ${ }^{1} \quad$ Bharani Kumar ${ }^{1} \quad$ Insha ur Rahman ${ }^{1}$ \\ ${ }^{1}$ Department of Anesthesia and Perioperative Medicine, King Fahad \\ Medical City Riyadh, Riyadh, Saudi Arabia \\ J Neuroanaesthesiol Crit Care 2021;8:220-222. \\ Address for correspondence Ravees Jan, MBBS, MD, EDAIC, \\ CHRM, Department of Anesthesia and Perioperative Medicine, \\ King Fahad Medical City Riyadh 11525, Saudi Arabia \\ (e-mail: janravees@gmail.com).
}

Abstract

published online

October 24, 2021
In the absence of cardiac pathology, premature ventricular contractions (PVCs) in neurosurgical patients frequently accompany subarachnoid hemorrhage, intracerebral hemorrhage, traumatic brain injury, or raised intracranial pressure. PVCs detected during preanesthesia assessment prompts detailed cardiac evaluation. Our 57-year-old 